\title{
STATE REGULATION OF DRUGS: WHO MAY SELL "PATENT AND PROPRIETARY" MEDICINES
}

A NETWORK of federal and state law guards public health by regulating the retail sale of drugs. All toxic, habit-forming, or otherwise dangerous drugs may be sold only on the prescription of a licensed practitioner. ${ }^{1}$ Under state pharmacy laws, such prescriptions may be filled-and such drugs sold-only by a trained pharmacist, examined and licensed by the state. ${ }^{2}$ Similarly, drugs which are normally harmless but require compounding by the retailer are salable only by pharmacists. ${ }^{3}$ As a result, the pharmaceutical profession clearly has the exclusive right to sell all drugs, except those which are not harmful and which are sold in the manufacturer's original package without further compounding.

1. Linder the Federal Food. Drug and Cosmetic Act, as amended, habit-forming drugs and other drugs unsafe for use without professional supervision because of their toxicity or method of use may be sold only on prescription or authorization for refill and must bear the legend: "Caution: Federal law prohibits dispensing without prescription." If thesc requirements are not met the drug is deemed misbranded. 65 STAт. 648 (1951), 21 U.S.C. $\$ 353$ (b) (Supp. 1952). Misbranded drugs are subject to seizure, and the seller to injunctive and criminal proceedings. 52 STAт. 1043 (1938), 21 U.S.C. $\$ \$ 332-4$ (1946), as amended, 62 Stat. 582 (1948), 21 U.S.C. $\$ 334$ (a) (Supp. 1952). These provisions apply to drugs from the time they enter interstate commerce until they are purchased at retail by the ultimate consumer. United States v. Sullivan, 332 U.S. 689, 696-7 (1948). Drugs which do not enter interstate commerce are governed by state food and drug laws, which are patterned after the present federal act or the earlier act of 1906. See Herrick, Drug Regulations in Drug Research and Development 360 (Smith \& Herrick ed. 1948).

Habit-forming drugs are also restricted to prescription sale by the Harrison Narcotics Act, 38 STAt. 786 (1914), as amended, 26 U.S.C. $\$ 2554$ (c) (2) (1946), and in 43 states by the Uniform Narcotic Drug Act, 9A U Uiform Laws ANnor. $§ 2,6$ (1951). Medicinal preparations containing harmless quantities of certain narcotics may be sold without prescription. 38 STAT. 789 (1914), as amended, 26 U.S.C. § 2551 (a) (1946); 9A UNiFora LAws ANnot. $\$ 8$ (Supp. 1952).

Poisons for non-medicinal purposes may be sold at retail without prescription by registered pharmacists if they are labeled with a warning and an antidote prescription, and if a register of all sales is maintained. See, e.g., $1 \mathrm{ME}$ REv. STAT. c. 62, $\$ 15$ (1944) ; N.J. STAT. AnN. $\$ 45: 14-19,45: 14-20,45: 14-22$ (1940) ; Cal. Health \& SaFetY Code $\$ \$ 20751,2075 z$, 20755, 20757 (Deering, 1952).

2. Laws in every state create a state Board of Pharmacy authorized to examine pharmaceutical college graduates and register them to practice pharmacy. It is unlawful for anyone other than a registered pharmacist to fill or compound the prescription of a medical practitioner. See, e.g., N.J. Stat. ANN. $\S \$ 45: 14-1,45: 14-6,45: 14-7,45: 14-13$ (1940) ; 2C N.C. Gen. Stat. $\$ \$ 90-55,90-61,90-72$ (1950); 11 Minn. Stat. AnN. $\$ \$ 151.02,151.06$, 151.10, 151.15 (1946).

3. The statutes do not distinguish between the compounding of dangerous drugs and of relatively innocuous ones. See, e.g., N.J. Stat. AnN. $\$ 45: 14-13$ (1940). This policy is unquestionably sound. Correct compounding requires skill. And the consequences of error may be disastrous, however safe the intended end product would be. 
It is unsettled. howerer, whether the pharmacist's monopoly also includes the right to sell this resiluary class of pre-packaged. non-prescription drugs. ${ }^{+}$ In general language, the pharmacy laws confine "drugs and medicines" to the drug store." Hint in every state except three," the statute contains a specific exemption, which pernits non-pharmacist merchants to sell "patent and proprietary" medicines.? This exemption has received two divergent constructions. The technical interpretation, followed in seven states. ${ }^{8}$ defines "patent

4. The class of noil-prescription (and therefore "not harmful"). pre-packaged, completely compounded medicines is imprecisely referred to as "over-the-counter items" or "selfmedicaments" by the literature of the drug trade.

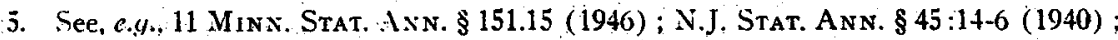
$2 C$ N.C. Ges. STat. \$90-71 (1950). The pharmacy acts which define "drugs" do so in the sweeping terms of the Federal Food, Drug and Cosmetic Act, 52 Stat. 1040 (1938), 21 U.S.C. \$321.(g) (1946), Such a definition embraces all articles recognized in the official pharmiceutical compendia. all other articles intended for the diagnosis, cure, mitigation, or - prevention of disease, and all articles, other than food, intentied to affect the structure or Eunction of the bodly. See, c.g., 21 LA. Rev. Stat. \$37-1171(3) (1951) ; 1-A Ono Gen. Cone ANN. \$1296-1(2) (Page, 1946): Wis. Stat. \$151.06 (1951).

6. Kan. Gen. Stat c. 65, art.16 (1949); NEv. Conp. Laws \$\$ 5040-62a (Supp. 1949); 4 N.M. Stat. An N. \$ $51-901$ (1941).

These laws are not entirely devoid of exceptions. The New Mexico statute allows sale of patent and proprietary medicines by non-pharmacists in tuwis, villages, and camps in which no registered pharmacist resides. 5 N.M. SrAT. ANN. $\$ 71-623$ (1941). Aid a Kansas court in effect created an exception by holding that hydrugen peroxide was not a "medicine" and therefore not encompassed by the pharmacy act, even though there was no statutory exemption. State v. Hanchette, $88 \mathrm{KAN} .864,129 \mathrm{Pac}$. 1184 (1913). In addition, the Kansas law now exempts "the usual domestic remedies and medicines." KAN. GEN. STAT. \$ 65-1611 (1949).

An exemption for "domestic" or "household remedies" often appears in statutes which also exempt patent and proprietary medicines. See. col., GA. Code ANN. \$ 84-1317 (Supp. 1951) : Ill. Rev. Stat. c. 9, \&36 (1951) ; 2C N.C. Gen. Stat. \$90-71 (1949). This seldom considered exemption has been construed to except only those medicines which come into such general use that their effects are understood by people without medical knowledge. 21 LA. Rev. Stat. § 37-1204 (1950); See Lewis v. Brannen, 6 Ga. App. 419, 422-3, 65 S.E. 189, 190-1 (1909).

7. Only a few of the statutes, embody an adequate definition of "patent and proprietary." See notes 8,14 infra.

8. The language of the Indiana and New Ilampshire acts compels the technical definition. 11-1 Inv. STAT. $\$ 63-1114$ (Burns, 1951) ("medicines of secret composition. . ."); 2 N.H. REv. Laws c. $256, \S 1$ (XI) (1942) ("certain individuals have the exclusive right to manufacture....").

Iowa, Mimesota, Oregon, Wisconsin, and probably New York have adopted the technical view by judicial decision. State v. Jewett Market Co., 209 Iowa 567, 228 N.W. 288 (1929); Minuesota v. F. W. Woolworth Co., 184 Minn. 51, 237 N.W. 817 (1931) ; State v. Combs, 169 Ore. 566, 130 P.2d 947 (1942) (harmless compendia articles may be sold by non-pharmacists who obtain permit from Board); State v. Wakeen, 263. Wis. 401, $57 \mathrm{~N}$ :W:2d 364 (1953); cf. Board of Pharmacy v. Matthews, 197 N.Y. 353, 90 N.E. 966 (1910).

The statute construed in the ilatthews case; suipra, contained no exemption. But the holding that the state can restrict to the pharmacy such harmless household remedies as spirit of camphor would seem to support a technical interpretation of the patent and proprietary 
and proprietary medicines" as those protected by letters patent or produced exclusively by the owner of a secret forniula or process. ${ }^{9}$ It does not exempt preparations listed in the United States Pharmacopoeia (U.S.P.) or other compendia." because formulae found therein are said to be neither patented nor secret." $A$ pplying this standard, one court recently held that aspirin, milk of magnesia, and camphorated nil are not proprietary medicines. ${ }^{12}$ Such a narrow construction gives pharmacists the exclusive right to sell all but a small exemption which was added to the statute after this decision. Board of Pharmacy v. Matthews, supra at 359, 90 N.E. at $96 \mathrm{j} \times$. No New York case has directly challenged the implication of Matth"is. But dictum in a later case involving the display of the words "Patent Medicines" by a non-pharmacist indicates that $\mathrm{New}$ York might now take a broader view: ['eople v. Bernstein, 237 App. Div. 270, 273, 261 N.Y. Supp. 381. 384 (2d Dep't 1932).

9. See Jinctt, Woolavorth, Combs, and Wakeen cases, supra note 8. A proprietary interest in manufacture of the preparation is the essence of the technical interpretation. This "wiership may be found either in a patent or in the secrecy of the formula or process of manufacture. The courts do not discuss the problem, but presumably a licensing agreement by which the "owner" permitted others to manufacture his medicine would not destroy its proprietary nature. Under the technical view aspirin was considered proprietary so long as its German discoverer was able to shroud his prucess. Sice State r. Jewett Market Co., 209 Iowa 567, 570-1, 228 N.W. 288, 289 (1929). However, once the patent expires or the secret is discovered and competitors begin to manufacture the preparation, it ceases to be proprictary and is salable only by pharmacists. Ibid. See 15 Iowa L. Rev. 369 (1.930).

10. The Linited States Pharmacopocia (U.S.P.) is published periodically by the United States Pharmacopoeial Convention whose membership is composed of federal agencies, national medical and pharmaceutical assuciations, and schools of medicine and pharmacy. Thl: Lnited States Pharmacipolial. Contextion-A bstract of Prockinl vis 107-108 (Decennial Meeting, 1950). Its object is to promulgate uniform standards for drugs and medicines in current use and to estalslish tèsts fur their strength, (quality, and purity. U.S.P. Revision XIV, p. xxviii (1950). The Natimal Formulary (N.F.) is published by the American l'harmaceutical Issociation for similar purposes. N.F., p. xxxv (8th ed. 1946). These compendia and uthers ( Nrw and Non-Offictal Remedies, Homeopathic Pharmacopoeia of THE (NITED STATES) are recognized by state and federal food, drug, and cosmetic acts hoth in defining "drugs" and in estahlishing standards of purity. Sec, c.g., 52 Stat. 1041, 1049 (1938), 21 U.S.C. $\$ 321(\mathrm{~g}), 351$ (b) (1946) ; 16 Fr. S. Stat. Ann. $\$ \$ 500.03(4)$, $\$ 00.14(2)$ (1943).

11. Sce, c.y., Minnesuta v. F. W. Woolworth Co., 184 Minn. 51, 54, 237 N.W. 817-18 (1931) (milk of magnesia L.S.P. not proprietary); Culver v. Nelson, - Minn. -, 54 ‥W.2A 7,13 (1952) (vitamiu preparations not proprietary). Beiore vitamins were recognized by U.S.P. they were considered food supplements, not medicines. Board of Pharmacy v. Quackenbush, 22 N.J. Misc. 334, 39 A.2d 28 (C.P. 1940).

The stated policy of buth U.S.P. and N.F. is not to list patented or secret preparations. U.S.P. Revisiox XIV, p. xxviii (1950) ; N.F., p. xxxv (8th ed. 1946). U.S.P. warns, however, that sume of the formulae listed may be protected by a patent. U.S.P. REVISION XIV, p. ii (1950). Obviously a formula listed in the compendia is no longer secret. But since the method of manufacture is not listed, it would seem that those U.S.P. items which require "know-huw" un the part of the manufacture still fit the technical requirement of a secret process. Furthermore, U.S.P. has emphasized that its primary objective is to supply the medical prufession with a list of medicines, not to aid in the enforcement of drug laws. U.S.P. Rrvision XIV, p. xi (1950).

12. State v. Wakeen, 263 Wis. 401,57 N.W.2d 364 (1953). 
class of pre-packaged, non-prescription medicines. ${ }^{13}$ In contrast, the seventeen jurisdictions which employ the common usagi interpretation ${ }^{14}$ read "patent" and "proprietary" as interchangeable descriptions of all harmless, pre-pacliaged medicines properly labeled with directions for use. ${ }^{15}$ Adopting this view, a court recently held that aspirin, mill of magnesia, and hydrogen peroxide are proprietary. ${ }^{16}$ This construction permits non-pharmacist merchants to sell all pre-packaged preparations deemed safe for use without prescription. ${ }^{17}$ In the

13. Patents are no longer granted for chemical formulae. Sce Fischelis, $I$ 'hat is a Patent or Proprietary Medicine? 46 Sctentific Mo*trily 25 (1938). It is still possible to patent a chemical process, but one court has said that patent and proprietsry medicines in the technical sense have become a "rare class." Sie Wrigley"s Stores v. Michigan Board of Pharmacy, 336 Mich. 583, 59 N.W.2d \&, 12 (1953).

14. Seren states have adopted the comm usage definition by judicial interpretation. People v. Heron, 34 Cal. App. 2d 755, 90 P.2d 154 (1939) (overruling previous enuneistion of the technical definition in People v. MeClain, 2 Cal. App. 2d 751, 33 P.2d 710 (1934)); State v. Ridgeway Drug Co., 324 III. App. 585, 59 N.E.2d 351 (1945) (aspirin C.S.P. and rochelle salts U.S.P. held proprietary) : Kentucky Board of Pharmacy v. Cassidy, $115 \mathrm{Ky}$. 690, 74 S.W. 730 (1903); Wrigley's Stores v. Michigan Buard of Pharmacy, 336 Mich. 583, 59 N.W.2d 8 (1953) ; State v. Stephens, 102 Mont. 414, 59 P.2d 54 (1936); State v. Geest, 118 Neb. 562, 225 N.W. 709 (1929); Pruprietary Ass'n v. Board of Pharmacy, 27 N.J. Super. 204, 99 A.2d 52 (1953).

Ten states have acts which define "patent and proprietary" in its broad, popular sense. These exemptions are of four types: (1) Oriminal pachage medicines suld to the general public under a trade name or similar protective device and cumply ing with the requirements of the Federal Food, Drug and Cosmetic Aet. Arrz. Core Axr. \$67-1501 (g) (Supp. 1952);

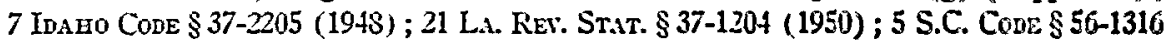
(1952) ; 3 Wro. Cosip. Stat. $\$ 37-1916$ (a) (Supp. 1953). (2) Original pacliage medicines protected by a trade device. 4 N.D. Rer. ConE $\$ 43-1502(4)$ (1943) (registered or copyrighted) ; 7 V A. Cone $\$ 5+399$ (11) (1950). (3) Original paclage medicines in compliance with the Federal Food. Drug and Cosmetic Act. Alu. Cone tit. 46, §256 (1940) ; 4 TE::3: CODE $\$ 7002.1$ (Williams, 1941) (if put up by a pharmacist). (4) All medieines except those which must be sold on prescription. Vт. Sтат. $\$ 6858(1947)$.

In practice, all four definitions are the same. All non-prescription medicines which enter interstate commerce must comply with the Federal Food, Drug and Cosmetic Act. One requirement is that the medicine be labeled with the preducer's name. 52 Srnr. 1050 (1938), 21 U.S.C. \$352(b) (1940). Such a label would satisiy the demand ior sale under a trade name. The need for a trade name is the result of effurts by courts and legislatures adopting the common usage definition to find some element of proprietorship in proprietary medicines. It is estimated that all but five percent ui the largest selling packaged medicines travel in interstate commerce. Communication to the YILE L.IW JOUR:LL from Lr. Frederids J. Cullen, Vice-President of the Proprietary Assuciation, dated November 25, 1953, in Yale Law Library.

15. Adequate directions for use are required by the Federal Foud, Drug and Cosmetic Act. 52 StAт. 1051 (1938), 21 U.S.C. $\$ 352(f)$ (1946).

16. Wrigley's Stores v. Michigan Board of Pharmacy, 336 Mich. 583, 59 N.W.2d 8 (1953). The court defined patent and proprietary as "pre-pacliaged, non-prescription, mass produced remedies put up for sale to the general public in the distinctive and original container, and under the trade name of the manufacturer..." Id. at 592, 59 N.W.2d at 12.

17. Since so-called "ethical proprietaries" are advertised only to the profession, they are not exempted by the definitions adopted in Arizona, Louisiana, South Carolina, Wyo- 
twenty-two jurisdictions where neither legislature nor judiciary has defined "patent and proprietary," the power to delimit the statutory exemption rests in the state Board of Pharmacy. ${ }^{18}$ At least one board has adopted the technical interpretation, ${ }^{19}$ while nine have accepted the common usage. ${ }^{20}$ In the remaining jurisdictions, the boards' attitudes remain unclear..$^{21}$

Recently, economic forces have kindled litigation concerning the meaning of the "patent and proprietary" exemption. Supermarkets are expanding their drug departments, ${ }^{22}$ and manufacturers of proprietaries hope to increase their sales by establishing new retail outlets. ${ }^{23}$ Four times within the last two years the markets and the manufacturers have asked the judiciary to overthrow a board of pharmacy's technical definition in favor of the common usage interpretation. ${ }^{24}$ Two courts have done so. ${ }^{25}$ The pharmaceutical profession has viewed these two decisions with alarm, ${ }^{26}$ especially because the profession has

ming, New Jersey, and Michigan, which require sale to the general public. Sce note 14 supra. Because demand for unadvertised items would be small, the non-druggist would probably not wish to stock the "ethicals." Drug products are generally costly" and slow moving. Digges, Retail Price Maintenance in Drug Researcn AND Developutent 563 (Smith \& Herrick ed. 1948).

18. These jurisdictions are: Arkansas, Colorado, Connecticut, Delaware, District of Columbia, Florida, Georgia, Maine, Maryland, Massachusetts, Mississippi, Missouri, North Carolina, Ohio, Oklahoma, Pemusylvania, Rhode Island, South Dakota, Texas, Utah, Washington, and West Virginia. The Board of Pharmacy is granted broad administrative powers, including power to adopt necessary rules and regulations and to prosecute violators. See, c.g., Okla. Stat. Ann. tit. 59, \$ 336 (Supp. 1952) ; GA. Cone Ann. \$\$ 84-1309 (Supp. 1951), 84-1311 (1937) ; 2 Conv. GEN. STAT. § 4464 (1949).

19. This is the Board of the District of Columbia. See note 21 infra.

20. Colorado, Florida, Maine, Maryland, Massachusetts, North Carolina, Oklahoma, Texas, and West Virginia. See note 21 infra.

21. A questionnaire was sent to the boards of pharmacy in the twenty-two states listed in note 18 supra. No reply was received from eight, and the replies of Delaware, Mississippi, Missouri, and Pennsylvania were ambiguous. One clearly indicated adoption of the technical view. See note 19 supra. And eight indicated use of the common usage interpretation. See note 20 supra. Replies to questionnaire in Yale Law Library.

22. Typical supermarkets now carry from 120 to 400 items in their health and beauty aids department. Communication to the Yale Law JourNal from National Ass'n of Food Chains, dated October 16, 1953, in Yale Law Library.

23. Communication to the YALE LAW Jourial from Carl Willingham, SecretaryTreasurer of the National Ass'n of Chain Drug Stores, dated October 2, 1953, in Yale Law Library. At present there are 54,000 retail drug stores, which the druggist contends are sufficient to supply the consumer market. Ibid.

24. Wrigley's Stores v. Michigan Board of Pharmacy, 336 Mich. 583, 59 N.W.2d 8 (1953) ; Culver v. Nelson, - Minn. -, 54 N.W.2d 7 (1952) ; Proprietary Ass'n v. Board of Pharmacy, 27 N.J. Super. 204, 99 A.2d 52 (1953) ; State v. Wakeen, 263 Wis. 401, 57 N.W.2d 364 (1953).

25. Wrigley's Stores v. Michigan Board of Pharmacy, and Proprictary Ass'n v. Board of Pharmacy, supra note 24.

26. See Herzog, 'Turixt Supermarket and Courts-Whither Pharmacys, 14 J. Ax. Pharmaceutical Ass'n 764 (1953). 
lost four percent of the packaged medicine trade since 1950.27 By the same token, the decisions may well encourage the supermarkets and drug manufacturers to press for acceptance of the common usage definition in the eleven states which still adhere to the technical view or which provide no exception for patent and proprietary medicines. ${ }^{28}$ A pitched battle between adrocates of the two interpretations seems to be under way.

The technical definition is objectionable. The public receives no protection from an interpretation which grants to the pharmacist the exclusive right to sell pre-packaged, non-prescription medicines. These items require no compounding. The pharmacist is relieved by statute from liability for injuries caused by the impurity, misbranding, or negligent compounding of such drugs..$^{29}$ He has no duty to analyze them, learn their ingredients, or warn purchasers of possible danger in their use. ${ }^{30}$ Similarly, he is not required to limit or record his sales. ${ }^{31}$ He commits a misdemeanor if he engages in the practice of medicine by recommending drugs to his customers. 32 In short, the pharmacist uses no professional skill and assumes no professional liability in the naked act of retailing harmless pre-packaged remedies. ${ }^{33}$ Often he does not even make the

27. In 1950,75 percent of the $\$ 920,980,010$ retail sales of packaged medieations were made in drug stores. In 1952 the drug stores' share dropped to 72 percent of $\$ 983,990,000$. These figures include $\$ 366,660,000$ fur packaged mudicine sold un prescription in 1950 and $\$ 110,000,000$ in 1952. With these amounts deducted, the druggists" share of "wrer-thecounter" (non-prescription) sales of packaged medicine dropfed from 59 percent in 1950 to 55 percent in 1952. See IThat Prople Spent in 1052 for Products Sold in Drup Stores, Drug Topics, August 10, 1953.

28. See notes $6,8,19$ supra.

29. See, c.g., 11 Mrax. STAT. ANn. $\$ 151.22$ (1946) (nu liability for quality of drugs sold in original package) : W. VA. Cone $\$ 2905$ (Supp. 1953) (same); 3 WYyo. Cosip. Srat. $\$ 37-1910$ (Supp. 1953) (same).

Such a provision nullifies the pharmacist's common law liability. Absent statutory immunity. he could be held liable to purchasers un a theory of implied warranty. And third persons might recover either for negligence in the sale of "inherently dangerous" articles, or else via strict liability based on the theory that the pure food and drug laws impose on the pharmacist an absolute duty not to sell bad items. See Prosser, Torrs 671-2, 676, 693 (1941).

30. Set Noel v. People, 187 Ill. 587, 593, 58 N.E. 616, 619 (1900) ; State v. Donaldson, 41 Minn. 74, 82, 42 N.W. 781, 783 (18S9) ; State v. Wood, 51 S.D. 4S5, 491-2, 215 N.WV. 487, 489-90 (1927). Also see West v. Emanuel, $198 \mathrm{~Pa} .180,47$ Atl. 965 (1901) (no action against druggist who, without prior analysis, sold fatally toxic patent medicine).

31. See State v. Childs, 32 Ariz. 22?, 23t, 257 Pac. 366, 369 (1927); State v. Wood, 51 S.D. $485,490,492,215$ N.IW. $487,489-90$ (1927). While the statutes permit unrestricted sale of pre-packaged medicines by pharmacists, they often limit the quantity of preseription drugs which he may sell. See, i.g., 11 Mrsx. Sr.tr. ANN. \$152.11 (1946) (prohibiting refills of barbital prescriptions). And poisun laws typically require the pharmacist to record his sales of toxic substances. See, e.g., id. $\$ 151.24$.

32. See, e.g., id. $\$ 147.10 ; 1-A$ OHro GeN. Cone $\$ 1286$ (Page, Supp. 1952); 3 Wyo. Contr. Stat. $\$ \$ 37-2007,37-2013$ (1945).

33. See State v. Donaldson, 41 Minn. 74, 81, 42 N.W. 781, 783 (1859) ("One man can do it just as well as another, if he can read the label un the paclage and malie change with the purchaser."). 
sale himself, leaving it to ordinary clerks or placing packaged drugs on selfservice shelves. ${ }^{34}$ If a specific item is found to be dangerous, the way to protect the public is to permit sale on prescription only. Barring that, sale in the pharmacy offers little which sale in the supermarket cannot duplicate. ${ }^{85}$

To be a valid exercise of the state's police power, a statute regulating the sale of drugs must bear a reasonable relation to public health. ${ }^{30}$ The objective of the pharmacy laws-to safeguard the public from mistakes in the preparation of medicines and from indiscriminate sale of dangerous drugs ${ }^{37}$-is above reproach. ${ }^{38}$ But restricting the retail of pre-packaged medicines to the pharmacist when he has no duty to guard against error or to limit his sales is an arbitrary and ineffectual method of achieving the legitimate end. ${ }^{80}$ For this reason pharmacy acts have been held to violate due process when they contained no exemption for patent and proprietary medicines. ${ }^{40}$ In those cases,

34. See Wrigley's Stores v. Michigan Board of Pharmacy, 336 Mich. 583, 594, 59 N.W.2d 8, 13 (1953). Such methods of retailing may constitute a misdemeanor, if a court does not consider such sales to be made under "personal supervision of a registered pharmacist." See, e.g., 11 Minn. STAT. Anv. $\$ 151.15$ (1946). Violation or no, the growth of the self-service drug store indicates the absence of any pharmaceutical function in packaged medicine sales.

35. Cases adopting the technical interpretation have been hard put to demonstrate how the public will be protected. These courts have suggested that the pharmacist will know where to procure pure drugs. See State v. Zotalis, 172 Minn. 132, 133, 214 N.W. 766 (1927). Or that he will know how to preserve them and how to "advise prospective purchascrs what products contain the vitamins they seek. ..." Culver v. Nelson, - Minn. -, 54 N.W.2d $7,14-15$ (1952). Or that he will protect the public from improperly compounded remedies. State v. Combs, 169 Ore. 566, 571-2, 130 P.2d 947, 949 (1942) (Quacre: how?). Or that he would have a tendency to protect the public by disapproving unsafe directions. In r' Gray, 206 Cal. 497, 502, 274 Pac. 974, 976 (1929). The most recent case, State v. Wakcen. 263 Wis. 401,57 N.W.2d 364 (1953), offers no reasons at all.

The pharmacist's self-interest as a businessman and his professional code of ethics might cause him to protect his customers' well being, but he is under no legal obligation to do so. See State v. Wood, 51 S.D. 485, 490, 215 N.W. 487, 489 (1927).

36. Liggett Co. v. Baldridge, 278 U.S. 105, 111-112 (1928) (invalidating Pennsylvania act requiring shares in drug store corporations to be owned by pharmacists) ; Pike v. Porter. - Mont. -, 253 P.2d 1055, 1056-7 (1952) (invalidating statute prohibiting use of word "drug" in advertising exempt household drugs) ; E. Fougera \& Co. v. New York, 224 N.Y. $269,277-8,120$ N.E. 642,643 (1918) (upholding ordinance requiring disclosure to board of health of ingredients of patent medicines).

37. See Kentucky Board of Pharmacy v. Cassidy, 115 Ky. 690, 705, 74 S.W. 730, 733 (1903) ; State v. Donaldson, 41 Minn. 74, 80, 42 N.W. 781,782 (1889).

38. See Liggett Co. v. Baldridge, 278 U.S. 105, 112 (1928); State v. Donaldson, 41 Minn. 74, 81, 42 N.W. 781, 783 (1889) ; State v. Wood, 51 S.D. 485, 488-9, 215 N.W. 487, 488 (1927).

39. See text at notes 29-33 supra.

40. Noel v. People, 187 IIl. 587, 58 N.E. 616 (1900) (act exempted only thase patent and proprietary medicines to be selected at the discretion of the board of pharmacy); State v. Wood, 51 S.D. 485, 215 N.W. 487 (1927) (no exemption); State v. Childs, 32 Ariz. 222, 257 Pac. 366 (1927) (no exemption) ; cf. State v. Donaldson, 41 Mim. 74, 42 N.W. 781 (1889) (act upheld by construing it to exempt patent and proprietary medicines). 
the statutes were held to deprive the non-pharmacist merchant of his property right to sell such articles, while producing no corresponding benefit to public health. ${ }^{21}$ This reasoning applies with equal force to the technical interpretation of "patent and proprietary." Such interpretation narrows the exemption to a small and completely arbitrary group of pre-compounded drugs."2 Patented or secretly processed items are in no way more fit for public consumption than other non-prescription preparations. ${ }^{23}$ In fact, they seem less suited for unsupervised sale than those remedies for which U.S.P.-guided by professional acceptance and public demand-has established uniform standards of purity. ${ }^{44}$

Courts should therefore hold that the technical interpretation violates substantive due process. ${ }^{45}$ Precedent for such a decision appears in two cases where state courts. accepting the technical definition, held pharmacy acts unconstitutional because they failed to exempt all harmless pre-packaged drugs. ${ }^{66}$ Courts are understandably reluctant to go this far and strike down the entire statute as unreasonable. But such drastic action is unnecessary. An interpretation which upholds a statute will be used in preference to one which would

41. Noel v. People, 187 IIl. 587, 594, 58 N.E. 616,619 (1900); State v. Wood, 51 S.D. 485, 488, 215 N.W. 487, 488 (1927); State v. Childs, 32 Ariz. 222, 226, 257 Pac. 366, 367 (1927); of. State v. Donaldson, 41 Minn. 74, 83, 42 N.W. 781, 783 (1859).

42. See note 13 supra.

43. Obviuusly a patent or secret recipe has nu relation to the safety of a medicine. The technical definition produces the anomalous result that only the newer, little demanded, and therefore relatively unreliable pachaged medicines are exempted. Sce People v. Herun, 34 Cal. App. 2d 755, 765-6, 90 P.2d 154, 159 (1939) (cuncurring opinion) ; Brief for Respendents, pp. 16, 103, State v. Wakeen, 263 Wis. 401, 57 N.W.2d 364 (1953). There it was shown that aspirin is restricted to the pharmacy but that if caffein is added to aspirin by a secret process it becomes a proprietary medicine which is freely salable even though more toxic.

44. See notes 10,11 supra.

45. The United States Supreme Court has never been asked to pass on the interpretation of the patent and proprietary exemption. If it should grant certiorari, it is doubtiul that the near-defunct doctrine of substantive due process would be revived. In this event, an equal protection argument could be made. See State v. Wood, 51 S.D. 485, 215 N.W. 487 (1927).

In another context the Supreme Court has rejected the technical definition of "proprietary." Ferguson v. Arthur, 117 U.S. 482 (1886) (customs case). But the Court is reluctant to interfere with state health regulations of this type. See, e.g., Roschen v. Ward, 279 U.S. 337 (1929). That case upheld a state statute prohibiting the sale of eyeglasses without an optometrist on the premises, but not requiring him to make an examination. Mr. Justice Holmes stated: "There can be no doubt that the presence and superintendence of a specialist tend to diminish an evil." Id. at 339.

Regardless of the Supreme Court's attitude, state courts could be asked to hold the technical interpretation to be a violation of due process. But for discussion of state courts' misuse of the substantive due process doctrine, sce Paulsen, The Persistence of Substantin'c Due Process in the States, 34 MIINN. L. Rev. 91 (1950); Note, 53 CoL L. REv. 827 (1953).

46. State v. Stephens, 102 Mont. 414, 59 P.2d 54 (1936) (act unconstitutional in restricting sale of original package medicines) ; State v. Geest, 118 Neb. 562,225 N.W. 709 (1929) (act unconstitutional in restricting sale of harmless U.S.P. and N.F. items). 
render it unconstitutional. ${ }^{47}$ Courts should leave the pharmacy acts intact, but satisfy constitutional requirements by adopting the common usage definition of "patent and proprietary." 48

Apart from constitutional issues, allowing non-pharmacist sale of all prepackaged, non-prescription drugs is a sound policy. ${ }^{40}$ These preparations still would be subject to laws which prohibit adulteration ${ }^{50}$ and misbranding, ${ }^{61}$

47. United States v. Delaware \& Hudson Co., 213 U.S. 366, 407 (1909). This rule of construction has been employed to read the patent and proprietary excmption into a pharmacy act. State v. Donaldson, 41 Minn. 74, 83, 42 N.W. 781, 783-4 (1889).

48. The two most recent cases adopting the common usage definition carefully avoid constitutional arguments and turn on a fabricated legislative intent, despite the meagerness of evidence indicating what the legislature in fact intended. In Wrigley's Stores v. Michigan Board of Pharmacy, 336 Mich. 583, 59 N.W.2d 8 (1953), the court did not mention any constitutional cases even though they were cited in Wrigley's brief and strongly support the court's decision. In Proprietary Ass'n v. Board of Pharmacy, 27 N.J. Super. 204, 99 A.2d 52 (1953), the court cited such cases with approval but only hinted at the constitutional issue in holding the Board's all-encompassing definition of "drugs" to bear "no reasonable relation to the public health, safety and weliare." Id. at $218,99 \mathrm{A.2d}$ at 60 . In its final judgment, issued two months after the reported opinion, this hint was diluted to a statement that the Board's definition was not reasonable. Final Judgment, Proprictary Ass'n v. Board of Pharmacy, Docket No. L-7734-50 P.W., N.J. Super Ct., September 21, 1953, in Yale Law Library. Both Wrigley's Stores and Proprietary Ass'n would bo stronger if they articulated the underlying premise, namely, that the alternative (technical) interpretation is unconstitutional.

49. The technical interpretation has proved unworkable; the vagueness of the standard of secrecy makes enforcement problematical. See Brief for Appellees, pp. 22-5, Wriglcy's Stores v. Michigan Board of Pharmacy, 336 Mich. 583, 59 N.W.2d 8 (1953). There the Director of Enforcement of the Board of Pharmacy was unable to testify whether or not "Ex. Lax" was patented or produced secretly. The common usage interpretation would provide the non-druggist merchant and the Board with a test of what remedies were excmpt; it would except any drug which is completely compounded and is not restricted to prescription sale by federal law or food and drug regulations. See Non-Drug Stores Win, Business Weck, May 20, 1939, p. 42.

50. Section 351 of the Federal Food, Drug and Cosmetic Act defines adulterated drugs as those containing filthy or poisonous substances, those packed under unsanitary conditions, those sold in poisonous containers, articles falling below standards set for them by official compendia, and other articles falling below the strength, purity, or quality stated on the label. 52 STAT. 1049 (1938), 21 U.S.C. \$ 351 (1946). Adulterated drugs may be seized and theiv manufacturer subjected to injunctive restraint and criminal liability. 52 ST 1 T. 1043 (1938), 21 U.S.C. $\$ 332-4$ (1946), as amended, 62 Stat. 582 (1948), 21 U.S.C. \$334(a) (Supp. 1952).

51. Section 352 of the Federal Food, Drug and Cosmetic Act deems misbranded a drug whose label does not contain conspicuously: (1) the name and address of the mantifacturer; (2) a statement of active ingredients; (3) the name and quantity of any habitforming substances and a warning of their habit-forming nature; (4) a statement of the quantity of alcohol and certain other dangerous substances; (5) adequate directions for use and warnings against use in conditions where it may be dangerous; and (6) precautions against deterioration. A drug is also misbranded when it is dangerous when tsed according to directions. 52 StAT. 1050 (1938), as amended, 21 U.S.C. $\$ 352$ (1946). Misbranded drugs are subject to the same sanctions as adulterated drugs. Sce note 50 supra. 
prevent false advertising of curative powers, ${ }^{52}$ and require that the safety of new drugs be proved before they enter commerce. ${ }^{53}$ Moreover, an increase in the number of retail outlets will serve consumers' convenience, and it may expand manufacturers' markets. The only one possibly hurt by adoption of the common usage definition is the drug store owner, who may lose much of the trade which traditionally has been his. ${ }^{-4}$ But he should nut be heard to complain. While holding his drug patronage captive, he has been free to expand his merchandising in all directions. Today almost half his sales are unrelated to drugs.55 And he will retain his prescription filling business. Certainly his plight does not seem tragic enough to justify sheltering him from competition through use of the technical definition-a legislated monopoly masquerading as a health regulation.

52. The Federal Food. Drug and Cosmetic Act deems misbranded any drug bearing a false or misleading label. 52 STAT. 1050 (1938), 21 U.S.C. \$352(a) (1949). The Federal Trade Commission Act prohibits the dissemination of any false or misleading advertising (other than on labels) likely to induce the purchase of urugs. 52 Srar. 114 (1938), 15 U.S.C. $\$ \$ 52-5(1946)$.

53. The New Drugs section of the Federal Foud, Drug and Cusmetic Act requires that an application be filed containing the results of investigations of the saiety of the preduct, a statement of its composition and methe of manufacture, specimens of the proffered latel, and samples of the drug itself. 52 ST.1T. 1052 (1938), 21 U.S.C. \$355 (1946). This section was drafted as a result of the 73 deaths caused in 1937 by Elixir Sulfanilamide, which had been tested only for flavor before being marketed. Sex. Doc No. 124, 75th Cong., 21 Sess. 1 (1937).

On a non-legal level the American Medical Association Council on Pharmacy and Chemistry also scrutinizes and approves new drugs under even stricter standards. See Smith, Professional Acceptanic in Drcg Research and Developanent 53 S-43 (Smith \& Herrick ed. 1948).

54. Most consumers would prakbly find it more cunvenient to purchase drug products in the supermarkets. In addition, the drus store wuld grobably lose sales boause the public associates the drug store with retail price maintenance and higher prices. Sce Herzog, supra note 26 , at 770 . This would seem to be true in spite of the fact that supermarkets could not sell items under fair trade contract below the established price.

55. In 1952, 53 percent of drug store sales were of health, toilet, and beauty items. The remainder is attributable to household supplies (e.1., polishes), stationery, magazines, and newspapers, photographic equipment, sundries (cluclss, light bulbs, etc.), tobacco, cunfections, soda fountain, alcoholic beverages, and "unclassified" items. This last eategory includes an ever-expanding variety of merchandise, such as electrical applianes, jewelry, cutlery, vacuum bottles, and musical supplies. The total amount of such sales increased from $\$ 9,390,000$ in 1950 to $\$ 61,690,000$ in 1952. See What People Spent in 1052 for Predisets Sold in Drasg Stores, Drug Topics, August 10, 1953. 